\title{
4. Solidarity and the Transnational Cultural Politics of Autonomy
}

The aim of this chapter is to understand international solidarity with and of the Mapuche as a form of transnational cultural politics of autonomy. Mapuche representatives from Wallmapu and from the European diaspora have transnationalised their cultural politics of autonomy since the 1970s and have woven a decentral, rhizomatic network of support and solidarity with other actors.

This chapter will develop its argument in three steps. First, it will outline a conceptual notion of autonomy as Mapuche cultural politics based on the historical experiences of autonomy of the Mapuche society, the shared horizon of autonomy amongst Mapuche organisations and communities today, and finally the conceptual approaches to autonomy within critical Mapuche studies. In the second step, the chapter will show how Wallmapu, understood as a site of conflict, resistance, and hope, became transnationalised through the agency of Mapuche representatives and a growing Mapuche diaspora since the 1970s. Finally, I will analyse contemporary international solidarity with and of the Mapuche as a decentral and rhizomatic network that is being woven by the agency of Mapuche representatives from Wallmapu and the European Mapuche diaspora. The central argument is that the cultural politics of autonomy of the Mapuche are being transnationalised and inform and ultimately shape the solidarity network. Whilst relations of solidarity with nonMapuche actors and organisations are being forged as a form of international and bilateral relations, internal dynamics of this network are rarely divulged to non-Mapuche outsiders and are thus kept hidden. The last feature of this network is that solidarity efforts are not limited to political action but include cultural and social dimensions.

Particularly, one experience early on in my ethnography pushed me towards considering how international solidarity is an expression of the cul- 
tural politics of autonomy of the Mapuche. In late 2014, I participated in a solidarity event in Cologne, the $2^{\text {nd }}$ Academia Mapuche, which brought together Indigenous Mapuche community members from Wallmapu, members of the Mapuche diaspora, and non-Indigenous, European supporters for a political and sociocultural exchange. On the last day of the gathering, the Mapuche community leaders from Wallmapu and the people from the Mapuche diaspora gathered in a room to organise a protest a few days after the event and to prepare a public statement. Non-Mapuche people, including me, were not invited to attend this meeting. As the evening went on, I became increasingly impatient, as I did not know how much longer the gathering might go on. I decided to leave, but not without informing two Mapuche women who I promised to take to their accommodation in my car. After some hesitation, I decided to interrupt the meeting and ask how much longer it might take. When I stuck my head into the room, it felt like everyone was immediately silent. I perceived a tense atmosphere in the room and that something important was going on. Now that everyone was staring at me, I realised that I was disrespectfully intruding on the meeting. Before I could say anything, one of the Mapuche leaders from Wallmapu, apparently at the centre of the discussion, raised his voice and asked without looking at me, "Is he with anyone?" Before anyone could reply, I quickly tried to explain the reason for my intrusion. I apologised and left the room as soon as I finished talking.

Besides the obvious awkwardness of the moment, I felt ashamed of claiming that I did not want to interrupt the meeting but nevertheless did. I ignored my own intuition about the importance of the Indigenous activists having a unique opportunity to meet amongst themselves and privileged my individual needs. I was also made aware of my discomfort of having only limited access to the solidarity network as a non-Indigenous supporter.

This anecdote is illuminating regarding how international solidarity with the Mapuche transnationalises their autonomy. Solidarity action with the Mapuche here is essentially solidarity work headed by the Mapuche and not dominated by non-Indigenous actors. The gathering I interrupted was a space created by Mapuche living in the European diaspora in order to discuss with community leaders from Wallmapu how solidarity action with their own people should be carried out under specific circumstances. European nongovernmental organisations (NGOs) and individual solidarity activists like me would only be invited to support these efforts. Solidarity action with the Mapuche, as this anecdote reveals, is centred around the efforts of the Mapuche community to maintain their autonomy within solidarity. In that moment, I ex- 
perienced in practice how Mapuche actors struggle to maintain their autonomy without necessarily negating the support of non-Indigenous actors or organisations. Finally, they managed to create an autonomous space within the context of international solidarity, thus transforming it.

This experience was significant for understanding the transnationalisation process of solidarity by reconstructing it based on Mapuche cosmology and political thought. The aim of this chapter is to translate Mapuche concepts into the study of the transnationalisation of their struggle by highlighting the ways in which Mapuche actors and concepts transform and transculturalise the networked structure of international solidarity.

\section{Autonomy as Mapuche Cultural Politics}

The first section of this chapter will develop a conceptual notion of autonomy as Mapuche cultural politics. First, it highlights the importance of autonomy in the historical experiences of the Mapuche society since the attempted conquests by the Spanish Crown until the twentieth century. Second, autonomy will be presented as the central concept and claim shared amongst many Mapuche organisations and communities today. Finally, this section engages with conceptual approaches and discussions around the idea of autonomy within contemporary critical Mapuche thought.

This is because the aforementioned ethnographic experience made me curious about the importance and the success of maintaining an autonomous space. I thus started to look for historical, as well as conceptual, clues about the importance of autonomist practices and thinking within Mapuche society. The struggle for autonomy is a cornerstone of historical experiences of the anticolonial resistance of the Mapuche, as well as of their contemporary political demands and intellectual elaborations. Due to the enactment of autonomy at the Academia, I wondered whether this prominence of practices and ideas of autonomy might also be the key to understanding the international solidarity efforts with the struggle of the Mapuche.

Struggles for autonomy by the Mapuche society date back to the first colonisation attempts of Wallmapu by the Spanish Crown from the middle of the sixteenth century onwards. The violent colonisation attempts were answered with heavy military resistance by the Mapuche. Because of that, the Mapuche society managed to maintain a certain degree of political autonomy and independence, impeding the Spaniards from advancing further south 
into their territory. This was possible because the Mapuche society of that period-contrary to that of the Incas or Aztecs-had a nonhierarchised social structure and each territorial social unit maintained its autonomy even though another one was defeated. The Spanish Crown thus needed to defeat "each one of the thousands of independent families" (Bengoa 2000, 39; my translation) in order to conquer the whole territory.

During the military resistance, the Mapuche society managed to maintain a de- or polycentral sociopolitical organisation without a unified political or military body. The core of this logic is the sociopolitical organisation of the Mapuche society as assemblages of-in ascending order-the family unit/rewe, the community/lof, and finally assemblages of communities/ayllarewe (Kaltmeier 2004, 69-74). The military resistance against the Spanish permeated the whole Mapuche society as a "total social fact, that comprises all social institutions and representations," becoming "the motor of the Indigenous, social machine' and serv[ing] the material and symbolic production of society" (Kaltmeier 2004, 35; my translation). If the main purpose of the anticolonial resistance was to maintain the autonomy of their society, other sociopolitical, cultural, and cosmological practices of that time were thus aligned to that aim.

After the Spaniards realised that they could not defeat the Mapuche militarily, the Mapuche and representatives of the Spanish Kingdom agreed to regularly hold so-called parlamentos, which became "a central dispositif ${ }^{1}$ to shape the relations between the Mapuche and the Spanish Crown" (Ibid., 56). Most of these resulted in bilateral treaties that determined conditions for peace, as well as more general political-administrative and economic agreements between the territories controlled by each side (Contreras Painemal 2010). Between 1592 and 1816, a total of 140 parliaments and treaties between the Mapuche society and other governments, mostly the Spanish Crown (and, in the nineteenth century, with Chile and Argentina), took place (Ibid., 208). These parliaments were the result of the military success of the Mapuche, forcing the Spanish Crown to enter in a political dialogue based on the principles of the customary law of the Mapuche, especially the az mapu (Ibid., 208). They were institutionally enduring spaces of bilateral negotiations, articulating ideas and struggles for autonomy through political instruments like the koyang-meetings or gatherings with long-lasting discussions and speech 
acts (Ibid., 41). Ultimately, they were expressions of "their constant and permanent struggle to uphold their singularity" in order to "avoid the emergence of one group representing them" (Ibid., 43-44; my translation).

In the nineteenth century, the independent nation-states of Chile and Argentina entered in negotiations with Mapuche representatives and-at first-respected their autonomy in bilateral treaties. The most important negotiation of that period between Chile and the Mapuche took place in 1835, with the parliament and Treaty of Tapihue, which established a frontier at the Bío-Bío river between the Mapuche nation and the Chilean nation-state, as well as the independence of the former (Ibid., 178-82). The most important aspect amongst a total of thirty-three agreements was that Chile recognised the "territorial and political independence of the Mapuche Nation, just as the Spanish did decades before" (Marimán et al. 2006, 83; my translation). In the decades to come, the Chilean nation-state entered in a process of gradual expansion in the southern and northern directions, which resulted not only in the violation of the Treaty of Tapihue but ultimately in the colonisation of Wallmapu and the military defeat of the Mapuche in 1883 (Bengoa 2000; Kaltmeier 2004, 78-96; Marimán et al. 2006, 83-113). Up to the present day, this military defeat has been determining for the relationship between the Mapuche and the Chilean society, since a once-recognised independent nation was conquered through the violation of a bilateral agreement between two parties. In that way, the Mapuche became a colonised society within the independent nation-state. Many contemporary claims for autonomy amongst the Mapuche society specifically relate to the historical experience of autonomy guaranteed in the Treaty of Tapihue, protesting its continuous violation by the Chilean state (Contreras Painemal 2010, 214) and the reproduction of the coloniality of power (Quijano 2014a). The latter describes the historical situation after 1883, in which colonial social structures have outlasted the formal independence of a nation-state. Accordingly, contemporary Mapuche historiography characterises the societies of Wallmapu (under the Chilean and Argentinean nation-states) as a colonial situation (Antileo Baeza et al. 2015; Marimán et al. 2006; Nahuelpan Moreno et al. 2013).

Though the struggle for autonomy did not cease in the colonial situation under the Chilean state after 1883, the circumstances for the Mapuche society changed drastically. Until the third decade of the twentieth century, the Mapuche society suffered a displacement from and colonisation of their territories. From approximately ten million hectares of independent Mapuche territory south of the Bío-Bío river, in 1930 only 500,000 hectares remained 
(Marimán et al. 2006, 116). In that period, the Mapuche society was violently pushed into Indigenous reservations, whilst receiving a communal ownership of the land, the so-called titulos de merced. ${ }^{2}$ Once this second colonisation was finished, "after 1927 there was a turning point in the political-legislative relations between Chileans and Mapuche, that can be described as a transition from segregation to assimilation" (Kaltmeier 2004, 109; my translation). The Mapuche society adopted their political strategies to fight for autonomy within this new historical situation and under the political, legal, and administrative structure of the state (Bengoa 2000, 361-96; Kaltmeier 2004, 116-245; Marimán et al. 2006, 129-218). Therefore, political actors of the Mapuche society started to develop different "intraethnic and interethnic mechanisms" and to look "for solutions in an organised way, leading to the development of diverse strategies ranging from strategic alliances with different political sectors to thinking about endogenous development guaranteed by the state" (Marimán et al. 2006, 212; my translation). Although these political strategies were heterogenous, the claim for autonomy remained steadfast.

For example, in 1931, the Federación Araucana, one of the newly founded Mapuche organisations within Chilean institutionality, ${ }^{3}$ and its chairmen Manuel Aburto Panguilef aimed for an Indigenous Republic on the basis of the political and cultural autonomy of the Mapuche (Marimán et al. 2006, 168-71). This goal, however, was abandoned quickly (Levanchy 1999).

The socialist government under Salvador Allende and the Unidad Popular was a "glimmer of hope" (Kaltmeier 2004, 129; my translation) for the Mapuche society, with several material, legal-administrative, and symbolic achievements in their benefit. But the dictatorship under Augusto Pinochet after 1973 changed the political circumstances again. Mapuche organisations, leaders, and communities suffered repression, were forcefully disappeared, or went into exile. Nevertheless, under the dictatorship and "in a climate of enormous repression, the Mapuche society ${ }^{4}$ was able to reorganise itself [...],

2 An English translation could be 'titles of mercy.'

3 Besides the Federación Araucana, worth mentioning are the Sociedad Caupolicán, and the Unión Araucana.

4 Amongst these organisations are the Consejos Regionales Mapuche, the Sociedad Araucana, the Centros Culturales Mapuche, Ad Mapu, Nehuén Mapu, Calfulicán, Lautaro Ñi Ayllarehue, and the Independent Movement for Mapuche (MUMI). Although politically and ideologically diverse, these organisations shared the goals of resisting a new the law that aimed to divide the Mapuche communities (Law 2.568), resisting the repres- 
positioning itself against the division of their land and, what is more, constructing an autonomous demand, which is still evident today" (Espinoza Araya and Mella Abalos 2013; my translation). Demands for autonomy were not only made public and addressed within the wider Chilean society (Ibid.), but also discussed internally amongst the organised Mapuche society ${ }^{5}$ (Levanchy 1999; Marimán et al. 2006, 239). Nevertheless, in that period a growing divide between urban Mapuche organisations with a leadership educated under Western standards and the rural, mostly subalternised Mapuche communities started to become a feature of the Mapuche society and its various sociopolitical expressions, which is still the case today (Haughney 2006, 59-62; Kaltmeier 2004, 163).

This historical context informs the present claims for autonomy and self-determination by the Mapuche movement in Wallmapu, as well as in the international solidarity efforts. The contemporary processes of political subjectivation amongst the Mapuche society thus constitute themselves "as an element and result of a history of conflicts, as a memory structure associated to that history and which is perceived as an identity, producing a wish and a decision to weave the heterogeneous and discontinuous particular experiences into a collective, subjective articulation" (Quijano 2014b, 314; my translation). Nevertheless, "only with the coming of democracy [in 1990], did concrete proposals for autonomy began to appear" on a more general scale amongst Mapuche communities and organisations (Levanchy 1999; my translation). This is why in the following I am going to conceptually outline the diversity of contemporary claims for autonomy within the Mapuche society by focusing on their common features. In doing so, I will focus on some of the politically most visible organisations of the Mapuche movement and intellectual discussions of Mapuche and non-Mapuche scholars from 1990 until the present.

In the second half of the twentieth century, the right to self-determination, and hence autonomy, became a fundamental pillar of the international (human and public) rights frame. It has been generally recognised as a right

sion, revitalize their culture, alleviate poverty and, finally, the need of a democratic government (Espinoza Araya and Mella Abalos 2013). 
of all people in the Charter of the United Nations in 1945, in the Charter of the Organisation of American States in 1948, and with some limitations by the American Convention on Human Rights of 1969. More specifically, the right to self-determination and autonomy for Indigenous people has been recognised on an international level in 1989 by Convention 169 of the International Labour Organisation (ILO) and in 2007 by the United Nations Declaration on the rights of Indigenous people (Habersang and Ydígoras 2015: 102-10). Some authors argue that (Latin American) Indigenous movements adopted the ideas of self-determination and autonomy under the influence of, or even as a result of, pressure from those international institutions. In that way, they would not be endogenous concepts or ideas (López 2015). As a matter of fact, sectors of the Mapuche movement of the 1970s and ' 80 s were influenced by debates with and within international organisations, as well as with other Indigenous people, on ideas of autonomy and self-determination (Haughney 2006, 62).

In any case, ideas on autonomy have been and still are a central element of sectors of the Mapuche movement in Wallmapu, considering that "in Chile, the Mapuche organisations with the highest level of mobilisation are [...] principally autonomist, taking into account the mentioned variations and plurality" (Saavedra Peláez 2002, 167; my translation). Mapuche organisations and communities have been developing demands for autonomy since the 1990s on an organisational and theoretical level. The most prominent conceptual elaborations of ideas on autonomy have been made within the organisational structures of the Coordinadora de Comunidades en Conflicto Arauko-Malleko (CAM), the Concejo de Todas las Tierras (CTT), and the Identidad Mapuche Lafkenche. The organisations themselves and their political strategies varied greatly, as did their ideas on autonomy (Levanchy 1999). By the end of the 1990s, the struggle for autonomy had become a central pillar of the most prominent Mapuche organisations and communities. One important characteristic of this "Autonomist Mapuche Movement" is that it managed to connect "cultural, territorial, identitarian, mnemonic, and political elements by aiming towards a qualitative change in its relationship with the Chilean state, sustained by the claim for autonomy" (Tricot 2013, 22; my translation).

Other important actors of the Autonomist Mapuche Movement, besides the already mentioned CTT, CAM, and Identidad Lafkenche, are the autonomist party Wallmapuwen, the Alianza Territorial Mapuche (ATM), ${ }^{6}$ the autonomous 
community of Temucuicui, the Coordinadora de Organizaciones Mapuche, the Parlamento Koz-Koz, and the Parlamento Autónomo de Malleko (Ibid., 318-27). The nonprofit Mapuche cooperative Kvme Mogen and the Asociación de Municipalidades con Alcaldes Mapuches (AMCAM) ${ }^{7}$ can also be considered part of that list. During my activist ethnography, I had the chance to talk to representatives of some of these organisations and communities. ${ }^{8}$ Their ideas on autonomy thus also inform their perspectives and opinions about the international solidarity efforts with their struggle.

In recent years, Mapuche and non-Mapuche scholars alike have paid more and more attention to the notion of autonomy within Mapuche society and political thought. Some of these efforts engage in conceptual and theoretical discussions about autonomy based on a Mapuche cosmology with the aim of contributing to the epistemological autonomy of Mapuche thinking (Nahuelpan Moreno et al. 2013, 17-18).

Looking at some of the more exhaustive discussions on Mapuche autonomy (Levanchy 1999; Marimán 2012; Tricot 2013), it becomes clear that there is no single and homogenous category within the movement. Contemporary organisations and communities all have the demand for autonomy as their central pillar but elaborate and approach it in different ways. The heterogeneity of the approaches to autonomy is, in that sense, itself an expression of the autonomy of those organisations and communities.

Another important conceptual feature is the identitarian and (ethno)national foundation and legitimation of autonomy through a different national belonging. Nevertheless, this foundation is not the result of an identitarian, ethnic, national, or racialised essentialisation, but rather should be understood as a dynamic and politicised positionality within the colonial Chilean society. ${ }^{9}$ Those who consider themselves part of the Mapuche nation today

7 Association of Municipalities with Mapuche Mayors.

8 Amongst them, Aucán Huilcamán of the CTT, Mapuche leaders associated with the CAM, community members and leaders associated with the Identidad Lafkenche, Jaime Huenchullán as werken of the autonomous community of Temucuicui, members of the board of Kvme Mogen, and the executive secretary of the AMCAM, Maurcio Vergaras.

9 Mapuche actors themselves critique this essentialisation on biological terms and claim that the shared Mapuche identity is rather the result of a collective experience of colonisation. For example, Llanquiray Painemal (interview with the author, June 16, 2017) argues that being Mapuche has much more to do with a political anticolonial 
consider themselves to be a colonised people (Marimán 2012, 121) and often reject the Chilean nationality (Levanchy 2005,8 ). Assuming a different nationality, I argue, is an important feature of autonomy, since "the demand for recognition as 'a people' cut[s] across ideological and tactical differences amongst organisations and institutions" (Haughney 2006, 73-74). In the words of two Mapuche leaders, "autonomy and self-determination are not political stances of some sector in particular; they are rights that emanate from our collective condition as a nation" (Caquilpán quoted in and Naguil in Haughney 2006, 74). Based on this shared nationality, sociopolitical Mapuche organisations make the claim for representing themselves politically, critiquing or even rejecting the legitimacy of Chilean political institutions. This leads to a generalised suspicion towards or even rejection of an engagement and participation within Chilean polity. Accordingly, this idea of autonomy is conceptualised in contrast or even in opposition to non-Mapuche sociopolitical institutions and organisations.

The idea of autonomy is also closely linked to a notion of territory and territoriality. Territory does not merely refer to the physical surroundings, but rather to an "existential space of self-reference" (Escobar 2010, 83; my translation). Also, for the Mapuche, territory is not only a geographical category but something much broader, which includes natural resources, religiosity, spirituality, and the organisational structures of society. Autonomy as a political concept is developed on the ground and in relation to a place-based politics based on a specific cosmology. The idea of autonomy is thus encapsulated within the multidimensional and holistic relationality of the Mapuche with their territory; the autonomy over a certain territoriality is what ultimately creates a Mapuche territory (Tricot 2013, 299-300).

Connected to that, autonomy for the Mapuche is the expression of a collective effort for sociopolitical organisation. The dissident subjectivities that are articulated are essentially produced in the community and its relation to the territory. ${ }^{10}$ For Hector Llaitul (Llaitul and Arrate 2012, 297), leader of the CAM, autonomy is part of reconstructing the social fabric, based on the basic territorial units-for example, families - towards higher levels of sociocultural and political organisations and ultimately in articulation with other

and decolonial positionality that can be assumed or rejected independently from ancestry.

10 See also the political philosophy of Central American Maya communities discussed by Tzul Tzul (2018). 
territorial units. In that way, autonomy for the Mapuche has to be understood as a multidimensional concept that concerns more areas of existence than the sociopolitical and organisational one. Furthermore, it has to be understood as a concept that emanates from the interaction with a territoriality, where people recreate the social fabric as an insurgent collectivity in a communal process.

Autonomy for the Mapuche also works to mediate difference, similar to a hinge, towards Chilean society (Marimán 2012, 278). On the one hand, autonomy works to mediate the maintenance of difference from Chilean society as well as to consolidate and reconstruct communal ties and, on the other, to organise contact with and translations into the Chilean society, aiming at its transformation. In that way, autonomy is both a centripetal and centrifugal force (Kaltmeier 2004, 348-49). Special attention must be paid to the centrifugal dynamic of autonomy in the discourse of Mapuche organisations and communities because of the unequal power relations in Chilean society. Transcultural relations between Mapuche and non-Mapuche take place within a hierarchical structure in which the centrifugal dynamics insist on its transformative and emancipatory potential, directed towards the non-Mapuche society (Ibid., 348-55).

Ultimately, these discussions are limited to certain conceptions of Mapuche autonomy by (Mapuche) intellectuals (Huinca Piutrin 2013) and thus exclude knowledges outside the intellectual, academic, and literary arenas of dispute mediated by the coloniality of knowledge (Lander 2005). This critique does not only demand an engagement with non-Eurocentric formalised ways of knowing the world, but is attentive to the pitfalls of incorporating these knowledges (Gutiérrez Rodríguez 2016). The challenge then is to centralise the knowledge production from and within Mapuche communities and their everyday practices and experiences without treating them as "pre-theoretical raw material" (Haritaworn 2012, 16). Such a conceptualisation of autonomy is different to that of Mapuche organisations, who define it as a political goal and achievement. In contrast, autonomy can be understood as a result of the experiences and practices of political and communal struggles. These micropolitical experiences emanate from the omnipresent and everyday struggles for territory, expressed in the Mapuche notion of kisugvnewvn. This idea refers to the right and to the capacity of each individual or collective to a form of self-government, based on territorial control and within wider networks of alliances, aimed at territorial or self-defence (Nahuelpan 2016, 117-18). 
The continuous presence of autonomy in not only the historical experiences but also in contemporary political mobilisations, intellectual elaborations, and micropolitical practices of the Mapuche indicates its significance within Mapuche society. Hence, it may well be argued that the concept and idea of autonomy plays a central role in the general collective memory ${ }^{11}$ of the contemporary Mapuche mobilisation (Habersang and Ydígoras 2015, 102; Kaltmeier 2004, 323-27; Nahuelpan Moreno et al. 2013, 11-21; Tricot 2013, 43-48). Historical memory is a crucial resource for Indigenous resistances and decolonialisation efforts, competing with, but not neglecting, Eurocentric perspectives (Quijano 2014c, 845). This memory is conceptualised as a form of resistance and counter-memory, transmitted orally within the communities and sometimes crystallised in demands by intellectuals and organisations. These historical experiences speak to the present, reorganising and rearticulating memories of autonomy in the contemporary context and challenging Eurocentric, linear concepts of storytelling and writing history.

This memory aims to (re)create a Mapuche identity, community, society, and culture through the ritualised practice of evoking an autonomous past, whose "point of reference [...] is the autonomous Mapuche society before the military conquest [by the Chilean state]" (Kaltmeier 2004, 327; my translation). Furthermore, it "manifests itself in the social praxis and in direct correlation with the political power" (Tricot 2013, 44; my translation). These arguments invite one to locate autonomy at the centre of what can be described as Mapuche cultural politics by assuming that

meanings and practices - particularly those theorized as marginal, oppositional, minority, residual, emergent, alternative, dissident, and the like, all of them conceived in relation to a given dominant cultural order - can be the source of processes that must be accepted as political. (Alvarez, Dagnino, and Escobar 1998b, 7)

It is particularly the historical memory of autonomy (in opposition to the historical and contemporary coloniality of power in Wallmapu) that informs the cultural politics of contemporary Mapuche mobilisation in Wallmapu and beyond. These ideas are conceptualised in a multidimensional way and as an integral part of the Mapuche culture, territory, and micropolitical practices, whilst recovering and reconstructing endogenous categories of knowledge. memory and culture, see Erll (2011). 
The notion of cultural politics helps to understand the struggle for autonomy beyond political ideas or intellectual efforts and reconnects them with the everyday practices of communal resistance. It connects the historically diverse but ongoing struggles for autonomy with the present and locates autonomy within a broader network from which Mapuche culture, identity, territory, cosmology, community, and society can be understood.

Yet the cultural politics of autonomy of the Mapuche does not only challenge the (Eurocentric) Chilean political culture. It is also at the centre of contemporary solidarity efforts with the Mapuche on an international scale, where Mapuche actors struggle to maintain their autonomy in the face of nonIndigenous organisations and actors. In summation, these cultural politics of autonomy defy the conventional ways of thinking and materialising international solidarity and advocacy efforts between the Global North and South. This is because, in this case, the Indigenous actors reaffirm their agency by maintaining their autonomy and challenge the potential paternalism of nonIndigenous actors.

What I experienced at the Academia Mapuche in Cologne was an expression of exercising autonomy within spaces and encounters of international solidarity. In what follows, I will focus in more detail on how these cultural politics of autonomy mould the rhizomatic solidarity network as a whole, particularly through the actions and mobilisation of the Mapuche diaspora since the 1970s.

\section{Transnationalising Wallmapu: Solidarity and the Mapuche Diaspora since the 1970s}

This section discusses how the conflict and resistance of the Mapuche in Wallmapu became increasingly transnationalised by the advocacy and solidarity activism of Mapuche representatives and a growing Mapuche diaspora since the 1970s. Transnationalising Wallmapu hereby refers to the transnationalisation of the Mapuche territoriality, understood as an "existential space of self-reference" (Escobar 2010, 83; my translation) within a capitalist and colonial conflict dynamic as well as a site of resistance and hope (Zibechi 2007).

Not much scholarly attention has been paid to the efforts of Mapuche organisations and communities in transnationalising their demands connected to the conflict in Wallmapu or of non-Mapuche actors and organisations 
in mobilising international solidarity. Some contemporary investigations address the transnationalisation efforts as one facet of historical or contemporary Mapuche resistance in Chile (Haughney 2006; Kaltmeier 2004; Marimán et al. 2006; Richards 2005) but only a few have made the transnationalisation their exclusive object of study by focusing on how Mapuche organisations and communities spread and frame their struggle and culture beyond Chile (Habersang and Ydígoras 2015; Salas Astrain and Le Bonniec 2015).

Based on these approaches, I am proposing to understand contemporary international solidarity with the Mapuche in connection to the transnationalisation efforts by Mapuche organisations and communities from the $1980 \mathrm{~s}$ onwards. ${ }^{12}$ However, I will put more emphasis on those practices of international solidarity that are the results of the broader sociocultural dynamics of the Mapuche society since the 1970s, particularly its diasporic experience. This is a more holistic approach to solidarity that includes both its political and sociocultural dimensions. Put differently, it is not possible to understand contemporary expressions of political solidarity with the struggle of the Mapuche without understanding the transnationalisation of their society since the 1970s.

The historical precursors of how the situation of the Mapuche has been transnationalised since the late 1980 s are fundamental to understanding any contemporary expression of international solidarity by or with the Mapuche. Despite the dictatorship of Augusto Pinochet, in the 1980s many new Mapuche organisations were founded, especially in urban contexts. They organised political and sociocultural resistance to the dictatorship and often renounced their previous party affiliations. With the struggle for autonomy at their centre, these organisations began to forge alliances with other actors and organisations on an international level.

For example, already in 1975, a Mapuche representative, Melillan Painemal, was elected Vice President of the Consejo Mundial de Pueblos Indigenas (CMPI), headquartered in Canada. Mapuche organisations from Chile also participated in the creation of the Consejo Indio Sudamericano (CISA) in Cuzco, Peru in 1980, contributing to the elaboration of common positions around anticapitalist and ethnonational demands (Marimán et al. 2006, 236). In the 
1980s, "some Mapuche activists had travelled abroad to international meetings of Indigenous organizations, to forums of the Working Group on Indigenous Peoples of the United Nations, or to sessions to revise the International Labor Organization's convention on Indigenous peoples" (Haughney 2006,62 ). At those meetings, they came into contact with other Indigenous peoples and politicians, as well as intellectuals sympathetic to their cause.

One of the most active Mapuche organisations in these early transnationalisation efforts was $A d M a p u^{13}$ and its leader Aucán Huilcamán. They increasingly shifted their political strategy from organising Mapuche communities in Wallmapu towards the national and international scale, with Aucán Huilcamán assuming responsibilities at the UN (Kaltmeier 2004, 190). By the early 1990s, the CTT was the main protagonist of Mapuche organisations transnationalising their demands. This happened at the cost of the CTT distancing itself from its community and territorial basis in the following years and up to present day (Marimán et al. 2006, 241). The CTT increased the alliancebuilding with other Indigenous movements in the Americas and participated actively in the continental commemoration of 500 years of Indigenous resistance in 1992. These developments correspond to an ideological shift of the organisation, by replacing their Marxist-Leninist political traditions with a panor neo-Indigenist ideology that had gained momentum across Latin America (Salinas Cañas 2005, 315).

Some elements of these early experiences of transnationalisation continue within contemporary international solidarity efforts. These include alliancebuilding with other Indigenous movements in the Americas; participation in international forums under the umbrella of the UN or ILO; and an examination of the regional autonomies in Spain, from which the Mapuche took and still take inspiration.

At the same time as these early transnationalisation efforts began to take form, the repression and persecution under the military dictatorship forced many Mapuche to leave the country. The Mapuche diaspora is defined as "the population forced to leave Wallmapu, its national territory, generally because of political and economic reasons" (Marimán et al. 2006, 261; my translation), but remains a controversially debated category amongst Mapuche intellectuals (Antileo 2014). Most importantly, the diaspora is defined as the Mapuche population living outside of their historical territory south of the Bío-Bío river, especially in other parts Chile, its urban areas, as well as in other countries. 
For the purpose of the present argument, I refer to the Mapuche diaspora exclusively as those who define themselves as Mapuche and live permanently in "external exile" (Rebolledo 2010; my translation) or "second exile" (Chihuailaf 2002, 169; my translation), meaning outside the nation-states of Chile and Argentina.

The external diasporic experience of the Mapuche is part of the forced exile many Chileans had to go through as a consequence of the military coup in 1973. ${ }^{14}$ The data on the specific Mapuche exile is very scarce, but a total of 50 Mapuche, who had to leave to Western European countries between 1973 and 1978, can be counted, arriving in the UK, France, Germany, Belgium, Sweden, Switzerland, and the Netherlands. According to Chihuailaf (Ibid.), 36 percent were peasants, 31 percent students, 13 percent working class, and 20 percent skilled workers and professionals. Other investigations speak of "hundreds of Mapuche" who ended up imprisoned and then in exile, but do not provide exact numbers (Rebolledo 2010, 181; my translation). Most of the exiled Mapuche were political leaders or at least were politically active in Mapuche peasant or student organisations or workers' or teachers' unions (Chihuailaf 2002, 169).

It is important to include a still unknown number of Mapuche children, who were forcefully taken from their families in Chile through illegal adoptions by foreigners in the 1970s and ' 80 s. A recent investigation revealed 488 children whose family and ethnic background remain unclear (López 2018). But it is safe to assume that a considerable number of these illegally adopted children were taken from Mapuche mothers. This is because most of the children were taken from mothers who lived in situations of high economic vulnerability and suffered repression by the military.

Some members of the first-generation Mapuche diaspora were imprisoned under the dictatorship and received support from international organisations like Amnesty International or the International Red Cross (Rebolledo $2010,181)$. For example, Rayen Kvyeh was imprisoned in the city of Concepción, where she had studied at the time. She was held in solitary confinement, was tortured, and was very sick by the time she was visited by German Amnesty International activists in 1979. Writing letters to these activists became for her "the door for communicating with the outside world" (interview

14 In total, 260,000 men, women, and children from diverse socioeconomic, cultural, and ethnic backgrounds had to leave Chile and resettle themselves in approximately 60 different countries in all five continents (Rebolledo 2010, 165). 
with the author, March 1, 2016). These letters were published in the $i z 3 w$ magazine by the solidarity group Chile Comité in Freiburg, Germany, making Rayen's case renowned in Germany and Chile. Finally, an employee of the German embassy in Chile helped Rayen get out of prison and took her on a flight to Europe. During a stopover in Montevideo, she and her young son were hidden by the airline staff in the pilot's cabin. She landed in Brussels and was received by the solidarity activist from the Chile Comité, who took her to Freiburg by car. She would then live in Freiburg for most of the 1980s. Rayen Kvyeh's story is a detailed, intimate, but also very powerful example of international solidarity. It also shows how the diasporic experience of the Mapuche in the 1970s was already framed by contingent and almost coincidental networks of solidarity between local groups in Europe and international organisations. Her story also makes visible some strategies and tactics of international solidarity that are still being used today.

The diasporic experience of the Mapuche in Europe changed the perception about their sociocultural situation in Chile. During his exile in Belgium in the 1980s, Godofredo Cotrena felt that the Mapuche and non-Mapuche exiles from Chile were put on the same level as simple foreigners. There he came to understand what racism was and how it has been naturalised in Chile, and was disappointed about the fact that political parties (of the Left) in Chile had historically ignored the Indigenous or ethnic question. Ultimately, however, the diasporic experience transformed the feeling of discrimination into pride of being Mapuche and created a sense of community amongst the exiled Mapuche (Rebolledo 2010, 181-85). In this way, the Mapuche diaspora made a similar ideological turn towards neo- or pan-Indigenist ideology, like the Mapuche organisations in Chile around the same time. In this case, however, the reason for this turn was the shared diasporic experience.

One organisational milestone of the Mapuche diaspora in Europe was the first meeting of approximately twenty-five Mapuche exiles in London between February 25-28, 1978 (Chihuailaf 2002, 170; Rebolledo 2010, 182). ${ }^{15}$ This encounter was important because it was where the Mapuche diaspora articulated themselves as autonomous political agents (Rebolledo 2010, 183), it created a space to collect and share experiences regarding the repressive realities under the Chilean dictatorship as well as the discrimination and racist structure of Chilean society, and finally because it was the foundational moment of 
the Comite Exterior Mapuche $(\mathrm{CEM})^{16}$ as a forerunner of contemporary organisational expressions of the Mapuche diaspora (Chihuailaf 2002, 170-71). They published information in European newspapers and journals, but also in outlets of the Chilean (non-Mapuche) diaspora, as well as on radio and television programmes. More interestingly however, they founded their own means of communication and began distributing information in several bulletins they published themselves ${ }^{17}$ (Ibid., 171-74).

The first-generation diasporic experience of the Mapuche in Europe constitutes a major precedent for transnationalising their demands beyond Chile. They developed a community spirit and sense of belonging amongst themselves whilst developing more and more critical notions of their condition as a colonised and discriminated collective within Chile. Based on that, they organised themselves autonomously from political parties, Chilean exiles, and European organisations, forming a solid organisational structure in the diaspora.

Similar to contemporary solidarity efforts, they managed to transculturalise the European solidarity scene by importing and rearticulating their experiences of sociopolitical organisation from Wallmapu (Rebolledo 2010, 183). At the basis of these experiences from Wallmapu and the diasporic efforts were the ideas of and the struggle for autonomy (Chihuailaf 2002, 174-75). During an informal conversation during my second fieldtrip to Wallmapu, one co-founder of the CEM also highlighted the importance of developing autonomous Mapuche organisations and strategies in the diaspora under the constant threat of being subsumed under party politics by non-Mapuche exiles. The struggle of the first-generation Mapuche diaspora in the 1970s and

16 The CEM was based in the UK, France, Germany, Belgium, and Switzerland and, between 1978 and 1984, organised further meetings in the cities of Paris, Liège, The Hague, Bern, and Frankfurt. Their efforts were directed at organising solidarity actions with (Mapuche) organisations and communities in Chile, informing the international public about their political and economic reality, and organising tours of Europe for leaders of the Centros Culturales Mapuche.

17 For example, the Buletín Informativo Mapuche was published from 1978 until 1982 in London with the support of the Indigenous Minorities Research Council, which also began to publish the bulletin Aukiñ in collaboration with the CEM in London from 1982 onwards. Between 1979 and 1981, the bulletin Amuleayñ was published in France. Those two publications then became the bulletin Huerrquen, which between 1982 and 1984 became the official medium of communication of the CEM. 
'80s transferred and translated the cultural politics of autonomy of the Mapuche to the European context. As the CEM ceased to exist by the middle of the 1980s, the Mapuche diaspora further came apart and organised itself increasingly on a national scale in their respective new home countries by the beginning of the 1990s (Ibid., 176).

Contemporary discussions consider the Mapuche diaspora, including the external Mapuche diaspora outside of Chile and Argentina, as a part of the Mapuche society and, in a way, its extension in other territorialities. The idea of a Mapuche diaspora challenges culturally essentialising notions of identity and highlights its heterogeneous, dynamic, and diverse character. The diasporic situation of the Mapuche is particularly understood within a colonial power structure, their displacement from the ancient territory of the Wallmapu, and its connection to sociopolitical and cultural demands for an (ethno)national autonomy (Antileo 2014; Chihuailaf 2002; Rebolledo 2010; Salinas Cañas 2005). There is only one other exhaustive research available about the Mapuche diaspora in Europe: an ethno-biography about the Railaf Zuñiga family, who left Chile during the dictatorship in the 1970s and settled in the Netherlands (Casagrande 2015).

During my committed ethnography in the European solidarity scene with the Mapuche, most of my interaction was with activists of the Mapuche diaspora, whom I met with either on several occasions or on a more regular basis. At the beginning of my research, I was not aware of the existence of the Mapuche diaspora in Europe and even less so of their central role in the solidarity efforts.

The first solidarity event I visited in Europe was the so-called $2^{\text {nd }}$ Academia Mapuche from October 23-26, 2014 in Cologne, which was organised by Alex Mora and Alina Rodenkirchen. Both identify as Mapuche and, at that moment, both were living in Cologne and were active in the German and European solidarity efforts. Roughly half of the approximately forty participants were first- or second-generation Mapuche living in Europe and engaged in solidarity action in their respective local contexts. ${ }^{18}$ On a second occasion, I came together with members of the Mapuche diaspora at a demonstration and conference in The Hague in May 2015, which was organised by the

18 They were based in Geneva and Lausanne, Paris, Copenhagen, and smaller cities in the Netherlands and Belgium. 
Mapuche foundation FOLIL, a mostly diasporic group based in the Netherlands, in collaboration with other members of the Mapuche diaspora form the Netherlands, Belgium, Germany, and Switzerland. The event was supported by the UNPO, Chilean exiles, and European solidarity activists. Based on my participation at this event, I was invited to the wetripantu in June 2015. Instead of being a publicly announced event or political rally, the wetripantu is a moment of coming together for the Mapuche diaspora and their families and friends, and has an intrinsic sociocultural and religious importance. The lingua franca of these events was mostly Spanish, spoken in many different accents, and, partially, Mapuzugun.

Through my participation at these events I became aware that the members of the Mapuche diaspora in Europe are the organisational core of the contemporary sociopolitical and cultural solidarity efforts in Europe. Their presence and agency are fundamental to understanding how contemporary solidarity activities with the Mapuche are organised.

It is notable that the Mapuche diaspora in Europe is keen to organise solidarity events autonomously and on their own terms, though they are supported by other non-Mapuche organisations, groups, and activists. For example, they receive logistical or financial support from organisations like the GfbV or the UNPO and individual non-Indigenous activists are invited to join. This means that the Mapuche (diaspora or guests from Wallmapu) are the protagonists of these events. They decide whom to invite, who shall give presentations, and what the schedule should look like. Other solidarity actors, like myself, are invited to these events and asked to engage in specific supportive tasks, like translating press releases, helping with the groceries, or assisting in the kitchen.

The organisation and political strategies of the second-generation $\mathrm{Ma}$ puche diaspora today are a direct result of the experiences of the first generation, who came to Europe after 1973 (Rebolledo 2010, 185). The political strategies and cultural politics of autonomy adopted by the first-generation diaspora were passed on directly to the second generation, sometimes within the same families. On several occasions, I was given testimonies by the Mapuche diaspora, ${ }^{19}$ engaged in solidarity efforts today, about their parents-mostly their fathers-teaching and instructing them how to organise solidarity activism with their people in Europe. They insisted that one of the most im-

19 Amongst them are the interviews with Andrea Cotrena, daughter of Codofredo Cotrena, and Llanquiray Painemal. 
portant lessons was how to organise solidarity in Europe autonomously from non-Mapuche organisations and people.

However, despite their crucial role in contemporary solidarity efforts in Europe, there is a struggle to recognise their efforts as Mapuche. For example, in a public interview by TeleSur with Andrea Cotrena during the event in The Hague, the interviewer identifies her as part of the "Chilean delegation" (TeleSur 2015). Andrea Cotrena refuses this classification and presents herself as a Mapuche woman living in Belgium. This situation was significant, as she claimed agency as a Mapuche woman and refused to be subsumed under Chilean nationality. With her intervention, Andrea Cotrena also challenged essentialising notions about Mapuche identity being fixed to one territoriality. Instead, she insists on the continuity of the struggle of the Mapuche within the diasporic experience by connecting her efforts with those of her father: "the struggle continues," she claims (TeleSur 2015). At the same time, she speaks as a member of the collective by talking in first person plural. She hereby establishes a translocal connection between the Mapuche in Wallmapu and in the diaspora, but also a generational continuity between her parents' and her own generation of Mapuche and their struggle.

An important element of the diasporic experience of the Mapuche is their access to higher education and their professionalisation in Europe (Salinas Cañas 2005,311 ). Many found opportunities for academically engaging with the reality of their people in Wallmapu at a time when Mapuche face(d) institutional limitations and discrimination in Chilean universities. But the diaspora today is not only the first or second generation of Mapuche exiled during the dictatorship. Many have also arrived and stayed in Europe in the recent decades and after the return of democracy. A major motive for the migration after 1990s was education. Alex Mora, who left Chile in 1995, describes himself as an "educational refugee" (interview with the author, November 28, 2015) and began studying at the Academy of Fine Arts Münster in 1997. Also, Rayen Kvyeh, who lived as a political refugee in Germany in the 1980s, explains that the diasporic experience in Europe meant access to education and knowledge. She describes Germany as a "source of knowledge" and notes that working for the magazine $i z 3 w$ "opened a world of political, social, historical, cultural knowledge about Africa, Europe, Arab countries, India, [and] the Americas" (interview with the author, March 1, 2016). These opportunities are further mobilised within solidarity efforts with the Mapuche.

Like in the 1970s and ' 80 s (Kaltmeier 2004, 365), the Mapuche diaspora today serves as a contact point for Mapuche representatives and delegates 
who travel to Europe to inform about the situation of the Mapuche in Chile at conferences, international organisations, smaller workshops, or single solidarity events. Jaime Huenchullán, werken of the autonomous community of Temucuicui, recognises the important role of the Mapuche diaspora in the transnationalisation of their struggle. He particularly appreciates the enthusiasm and the logistic support of the "peñi" during his visit to Europe (Radio Mapuche 2015). The Mapuche diaspora is in close contact with Mapuche organisations and communities from Wallmapu and thus supports the organisations and coordination of their visits to Europe. Activists from the Mapuche diaspora invite the delegations from Wallmapu to stay at their houses, translate their speeches, and organise the overall logistics. Of strategic importance are those solidarity groups of the Mapuche diaspora who live in cities close to the headquarters of international or supranational organisations, like Geneva or Brussels (the UN and the European Parliament). The presence and the support of the Mapuche diaspora provide the representatives from Wallmapu with spaces autonomous from non-Mapuche organisations and actors. The Mapuche diaspora thus guarantees that the delegations maintain their cultural politics of autonomy.

Similar to the first generation, the Mapuche diaspora today has a strong sense of community. Their joint efforts in solidarity with their people thus exceed the mere political sphere. The political work of solidarity with the struggle of the Mapuche in Wallmapu is intrinsically connected to a sense of becoming part of, and belonging to, the Mapuche. Alex Mora describes how political work and interpersonal bonding went hand-in-hand as he started to see other Mapuche living in Europe as his family and feeling accepted (Alex Mora, interview with the author, November 28,2015 ). The solidarity work thus contributes to reconstructing the social fabric and cultural traditions of the Mapuche.

This is because many of the solidarity events organised by the Mapuche diaspora do not only have a political dimension but serve to celebrate the survival of, revitalise, remember, or restore Mapuche culture (Smith 2008, 142-63). Activists from the Mapuche diaspora wear their traditional clothes and jewellery; they use Mapuche instruments, like the trutruka or kultrun ${ }^{21}$ in their traditional roles; and display the Mapuche flag, wenufoye. Especially

\footnotetext{
20 Brother(s).

21 Traditional Mapuche horn and drum, which are used to announce speeches or call for attention.
} 
the celebration of the wetripantu is a crucial example of how Mapuche culture and traditions are celebrated and translated within the diaspora. Solidarity events are also organised according to certain Mapuche rules and start, for example, with a brief welcome prayer jejipun. For example, Aucán Huilcamán, who participated via Skype at the event in The Hague, could not hide his joy and surprise when hearing a Mapuche woman's jewellery rattling through the microphone. Whilst these examples correspond to the centripetal logic of revitalising Mapuche culture amongst themselves, presenting cultural symbols to the non-Indigenous world has a more strategic use and is disconnected from everyday life. ${ }^{22}$ The celebration and display of Mapuche cultural symbols is rather a part of the community-building process in the context of solidarity efforts by the diaspora. This is a clear sign of the cultural embeddedness of the politics of autonomy within solidarity efforts. Thus, the cultural politics of autonomy not only relocate political strategies of solidarity to the European context but also revitalise the social fabric and cultural traditions.

Whilst the first-generation Mapuche diaspora was widely dominated by a Mapuche men (Rebolledo 2010), today the diaspora is characterised by a strong female presence, and many Mapuche women are protagonists of the solidarity efforts. This is interesting, as the thesis that "women had a substantial role in the development of a reconstruction process of the Mapuche society" (Leiva Salamanca 2015, 168; my translation) also becomes true for the Mapuche diaspora in Europe and their political efforts. Similarly, "the multifaceted ways by which Mapuche women recreate cultural practices [...] in culturally modified post-migration urban spaces" (Becerra et. al. 2017, 14) in Santiago de Chile, can be diagnosed for the external diasporic context in Europe, particularly in solidarity encounters. This is because Mapuche women in Europe today do not only have a prominent role during public solidarity events, but also recreate cultural practices like food preparation (zeuma iyael) or communal conversations while drinking mate te ${ }^{23}$ (matetun) in those encounters. In that way, mostly Mapuche women are in charge of those "meanings, images, memories, wisdom, customs, and practices that constitute the basic inputs to recreate cultural practices" and which "help [to] maintain social configurations and ways of inhabiting public and private spaces that empha-

22 I will discuss this aspect in more detail in chapter five.

23 Mate is a popular, caffeinated tea from South America, particularly consumed in Chile, Argentina, Uruguay, and Southern Brazil. 
size community solidarity, indigenous knowledges, and reciprocity" (Becerra et. al. 2017, 14-15).

The prominent role of Mapuche women in public solidarity events organised by the diaspora further challenges the European political arena as a historically male-dominated space, in which Indigenous women intervene by denouncing human rights violations or claiming Indigenous, and particularly Indigenous women rights (Richards 2005). At the same time, their visibility confronts Eurocentric and colonial imaginaries of Indigenous cultures and societies as male-dominated and patriarchal, ${ }^{24}$ whose women need to be saved by white men (Spivak 1988).

\section{Weaving International Solidarity}

With the transnationalisation of their cultural politics of autonomy, Mapuche representatives and the Mapuche diaspora weave an international network of solidarity. By maintaining and transnationalising their cultural politics of autonomy, international solidarity with the Mapuche is essentially solidarity by the Mapuche themselves. The last section sheds light on some elements of this transnationally woven network, which becomes visible by focusing on the autonomous cultural politics. These characteristics are the decentral and rhizomatic network structure, solidarity as international and bilateral relations, and the hidden transcript of solidarity. The last feature of this network is that solidarity efforts are not limited to political action but include cultural and social dimensions as well. These characteristics are the results of the transnationalisation of the cultural politics of autonomy by the Mapuche diaspora and Mapuche representatives from Wallmapu. The organisational structure of the Mapuche movement, organisations, and communities is not limited to the national sphere but becomes entangled with international and transnational struggles (Kaltmeier 2004, 364).

The first characteristic is that international solidarity with the Mapuche is organised as a decentral and rhizomatic network. The de- and polycentral sociopolitical organisation is a major characteristic of the Mapuche society and has been a crucial factor in maintaining independence against the Spanish Crown. Also, contemporary Mapuche mobilisations, and particularly the more whites and/or Europeans, for example in Bolivia (Rivera Cuscanqui 2018, 100-136). 
autonomist expressions in Wallmapu, are essentially decentral and composed of a multiplicity of organisations, communities, and their demands. A similar characteristic applies to the organisations and groups organising solidarity with the Mapuche.

In Europe, two decentral networks are a structuring force and nodal points (Purcell 2009) of the solidarity efforts: the $\mathrm{CME}^{25}$ and the IDNMP. The CME was founded at a trawvn ${ }^{26}$ in February 2012 in Amsterdam. A total of twelve organisations from all over Europe, amongst them local groups of the Mapuche diaspora, participated in the meeting. ${ }^{27}$ Those organisations agreed on the need to improve and consolidate the coordination of solidarity organisations in Europe and pressure European and international institutions to support the Mapuche. They met at a second trawvn in 2013 in Brussels (Mapuche NL 2012), ${ }^{28}$ committing themselves to:

1) Centralize the documentation, information and planning of activities of member organisations.

2) Strengthen joint work to denounce and raise awareness about the situation facing the Mapuche People.

3) Continue advocacy work at the international institutions for the rights of the Mapuche People. (European Coordination to Support the Mapuche People 2013)

The Academia Mapuche in Cologne in 2014 can also be understood as a meeting of the CME, now almost exclusively composed of diasporic Mapuche groups from different European countries.

The second decentral solidarity network in Europe is the IDNMP, connecting local groups in the cities of Oslo, Hamburg, and Milan. It primarily organises solidarity events and protests in those cities, trips by Mapuche

25 This network was also known as European Coordination to Support the Mapuche People or European Mapuche Coordination (Mapuche NL 2015a).

26 Meeting or gathering.

27 Amongst them were the FOLIL foundation, the Ethical Commission Against Torture, Critical Students Utrecht (both from the Netherlands), the UNPO (the Netherlands and Belgium), Tierra y Libertad para Arauco, Nuevo Concepto Latino, and France Libertes (France), Comabe and FEWLA (Belgium), the GfbV (Germany and Italy), and the Colectivo Mapuche de Girona (Spain).

28 This second meeting from May 10-12, 2013 was joined by the organisations Comabe and FEWLA (Belgium), FOLIL (the Netherlands), the GfbV (Germany), Tierra y Libertad para Arauco (France), and UNPO (the Netherlands and Belgium). 
delegations from Wallmapu to Europe, and engages in informational politics on social media. Other organisations that have contributed to solidarity efforts with the Mapuche in recent years are the 3. Welt Forum Hannover, the Forschungs- und Dokumentationszentrum Chile-Lateinamerika in Berlin, Nuke Mapu in Frankfurt, and the Asociación KIMUN and Red Mapuche Suiza in Switzerland.

Together they compose an open and decentral network of small-scale, lowbudget, and mostly locally bound organisations all over (Western) Europe. Their most active members are part of the first and second generation of the Mapuche and Chilean diaspora in Europe. In that way, they mobilise their close personal, political, and family connections to Latin America, Chile, or Wallmapu for solidarity action. The sum of these organisations does not have a clear centralisation, hierarchy, or permanent structure. Instead, the network is decentralised, connecting different European countries and cities and aiming to work on equal terms and on a horizontal basis with each other.

An expression of the de- and polycentral sociopolitical organisation of the Mapuche in Chile is the lack of one single, prominent spokesperson. The same happens within the solidarity network, since no particular individual or group of activists are made prominent. The network does not put forward a leading figure; rather, it is the situation of the Mapuche in Wallmapu that is in the spotlight. Their prominence is rather a result of being connected and committed to the same issue: denouncing human rights violations in Chile and supporting the Mapuche resistance. In that way, the particular situations and events (the different trawvn, the Academia, etc.) in which these organisations come together are what composes the networked structure. In short, the connections are more important than each individual hub.

The lack of a central organisation of this network prevents the emergence of a single group claiming to represent the Mapuche in Wallmapu. In contrast, most of the solidarity events are organised together with representatives from Wallmapu. As guests visiting Europe or connected digitally, they speak for themselves and maintain their autonomy whilst doing so. The decentrally connected groups rather provide a platform in Europe, from where Mapuche representatives can address their problems, struggles, and demands. For Alex Mora (interview with the author, November 28, 2015), the help here in Europe is only used as a support. He further explains that he does not aim to become the spokesperson of Mapuche communities because everyone has their different way of thinking. For him, this is an important aspect of the freedom of the Mapuche. His explanation is similar to the analysis of the political delib- 
eration system amongst contemporary Mapuche organisations in Wallmapu (Kaltmeier 2004, 306-22). In a dynamic of "leading by obeying," a political leader must first consult the opinion of the community; second, the leader must find a normative consensus from these differing positions; and third, the leader must put this articulated consensus in (public) circulation. ${ }^{29}$

For international solidarity efforts, leading by obeying means being an extension and support of the struggle of the Mapuche in Europe. Jaime Huenchullán recognises that more and more international groups and individuals "began to adhere themselves" to the political positions of Temucuicui, contributing to their struggle and the proliferation of the solidarity network (Jaime Huenchullán, interview with the author, March 20, 2016). In that way, international solidarity is part of their struggle and not vice versa. This is a clear challenge to colonial and paternalistic forms of international solidarity, which support struggles in Global South as long as they fit in their political parameters.

Nevertheless, there is also the critique that international solidarity efforts with the Mapuche do not manage to portray the diversity of political and sociocultural positions from Wallmapu. Isabel Cañet, from the autonomist party Wallmapuwen, laments that the international solidarity efforts focus too much on the political prisoners and land rights. Whilst she considers these issues to be crucial, "it needs to expand a bit more and to open up a bit more to all the topics that are really present here" (Isabel Cañet, interview with the author, February 24, 2016).

A major advantage of the decentral networked structure is its spontaneity in organising protests against symbols of the colonial and capitalist oppression and domination in Chile. These symbols, similar to a many-headed hydra, are deterritorialised, transnational, and have a global reach (Linebaugh and Rediker 2013). They are followed and challenged by the decentral solidarity network and become the targets of political protest in support of the Mapuche. Two experiences highlight the contingent protests against symbols of the many-headed hydra.

One central symbol for human rights violations by the Chilean state has been the former Chilean President Michelle Bachelet, whose visits to Europe

29 A similar political dynamic is at the core of the political philosophy of the Zapatistas, which "is aimed at inverting the traditional relationships of hierarchy within the organisation. Leadership positions are rotated, and there seems to be a vacuum of the authority at the center" (Hardt and Negri 2004, 85). 
have been continually protested by the Chilean and Mapuche diaspora. On one occasion, the CME, together with Mapuche representatives from two communities in resistance, organised a public demonstration after the Academia Mapuche in Cologne in front of the venue where Bachelet was meeting with representatives of the private sector and German politicians (Cárdenas 2014). On a second occasion, Bachelet visited the CELAC Business Summit with the EU on June 4, 2015 in Belgium, where she was also rewarded the Doctor honoris causa at the University of Leuven. Three Mapuche women from the Mapuche diaspora (in traditional dress) protested the reward and Bachelet's speech silently whilst holding up posters denouncing the persecution and criminalisation of the Mapuche protest in Wallmapu (Mapuche NL 2015b).

Another example of the contingent and decentral solidarity efforts against the multi-headed hydra of the Chilean state was the tour of the Chilean military ship La Esmeralda in summer 2015 to Europe. The ship is known for having served as a site for detaining and torturing political prisoners, amongst them Mapuche, during the dictatorship of Augusto Pinochet in the 1970s. The ship made a tour to Europe and Australia, and was heavily and publicly protested by the Chilean and Mapuche diaspora in the cities of Amsterdam (Pieters 2015) and London (Doward 2015). A local radio in Bremen also reported on the protests in the city of Bremerhaven (Radio Bremen 2015).

These examples show how the network manages to follow signs and signifiers (the many-headed hydra) of the conflict in Wallmapu to Europe and protest against them. It thus can react spontaneously to events that are covered by Chilean media and put the protest and demands of the Mapuche on the public agenda. Nevertheless, this contingent decentrality is an organisational, logistical, and financial challenge for activists and groups in Europe, as Andrea Cotrena points out (The Hague, group discussion, May 5, 2015). It is also a reactive effort, protesting the many-headed hydra whenever it sticks out one of its heads in Europe. The network (re)produces itself according to the contingency and takes up a temporal shape in the form of, for example, e-mail groups that are set up only for a particular protest.

The metaphor of the hydra can also be turned on its head in order to understand a particular aspect of the Mapuche resistance. The hydra can help to explain the difficulty in breaking the resistance of the Mapuche: if one head of the hydra is chopped off, two other heads will grow. This also refers to the most famous resistance shout, marichiweu, which means that for each Mapuche who falls, ten more will rise. 
Such de- and polycentric and contingent network structures of contemporary social movements and political protests can be described as rhizomatic (Day 2004; Khasnabish 2013; Purcell 2009). Characteristics of a rhizome are that it "has no beginning or end; it is always in the middle, between things, inter-being, intermezzo. [It] is alliance, uniquely alliance" (Deleuze and Guattari 2005, 25). Furthermore, it "connects any point to any other point, and its traits are not necessarily linked to traits of the same nature" (Ibid., 21). The idea of the rhizome is thus particularly helpful to understand contemporary political mobilisations and protests because it

encourages an explicit consideration of the way everything from institutions to social change movements to subjectivities are brought into being through a process that is intrinsically relational and has no meaning or direction outside of that relationally. In this regard, the rhizome as a conceptual and analytic tool is a metaphor through which to explore different dynamics and consequences of contemporary social movement activity. (Khasnabish 2013 , 83)

With the metaphor of the rhizome it is possible to identify the central characteristics of the solidarity network. Instead of having a fixed network structure, the solidarity rhizome consists only of connections of its autonomous parts. Also, the network becomes visible in particular moments of protesting against the many-headed hydra until it disappears again or comes to surface in a different shape. In that way, the map of the rhizome is never fixed but "must be produced, constructed" (Deleuze and Guattari 2005, 21). Thus, the solidarity network has no fixed structure or organisational form but creates "a space defined only by the connections, encounters, and relations that occur within it" (Khasnabish 2013, 83).

Instead of considering the rhizomatic aspect an expression of "the postmodern transition of organisational forms" (Hardt and Negri 2004, 85), I see it rather as an outcome of the experiences, historical memories, micropolitics, and sociopolitical organisations around the cultural politics of autonomy by the Mapuche. Conceiving these organisational features as a product of postmodernity would silence the alternative cosmologies and political thought of the Mapuche that inspire this rhizomatic network. Without considering the cultural politics of autonomy behind the international solidarity network, the sociopolitical and cultural dimension of these efforts would not be tangible. At the same time, Western thought provides a helpful category through which the international solidarity efforts can be grasped. The challenge is to pro- 
ductively combine both epistemological perspectives without silencing (and, instead, multiplying) their heuristic strength.

Finally, if a "rhizome has neither a beginning nor an end" (Deleuze and Guattari 2005, 41), the de- and polycentral struggle of the Mapuche can be considered intrinsically transnational and translocal. The concept of a rhizome allows to focus on the encounters of solidarity across different places and geographies without reducing them to a Chilean issue. Rather than reproducing hierarchies between the centre and the periphery or between the global and the local, the rhizome highlights the continuation of a far-away struggle in Europe under the principle of the cultural politics of autonomy.

During a visit to Europe in 2016, Jaime Huenchullán explains another important feature of the transnationalisation of their struggle:

And on the [...] positive side or on the good side (pause), which is why [...] the decision was made, right, that people come from the outside [...], so that (pause) the [Chilean] state cannot say that the Mapuche people are (pause), I don't know, that they are alone! Because if all the nations, states, countries have the possibility to, I don't know, sign treaties, agreements, arrangements, alliances - the Mapuche people have the same right of interacting, looking for allies, looking with whom to have a conversation, with whom to establish —even if they are small—agreements, and that is part of the right of [...] the Mapuche people for self-determination. (Jaime Huenchullán, interview with the author, March 20, 2016)

He argues that the Mapuche have the same right as every other nation or state to engage freely in international relations with other political entities. Essentially, he suggests to consider the transnationalisation of their struggle and hence the international solidarity efforts as emanating from their right to self-determination and autonomy. Building alliances in solidarity with other actors beyond the Chilean nation-state is thus a result and expression of the cultural politics of autonomy. In that way, Mapuche representatives transform international relations of solidarity into forms of bilateral international relations and foreign policy with other actors. They hereby exercise the right to autonomy not only in relation to the Chilean nation-state, but also to supranational and international actors and organisations. The cultural politics of autonomy are in this way transnationalised and frame the international solidarity network. Accordingly, this network appears as a web of international relations between the Mapuche and representatives of other nationalities. Instead of acting as a minority within a particular nation-state demanding 
recognition, delegations from Wallmapu and actors of the diaspora act as representatives of an autonomous nation.

One important pillar of this international (solidarity) policy is the interaction with other Indigenous nationalities from Latin America and across the globe as a continuation of the experiences of the 1970 s and ' 80 s. Such encounters and relations are fundamental for establishing a pan-Indigenous solidarity based on mutuality and horizontality that counters paternalistic ideas (Kaltmeier 2004, 364). In several conversations with my Mapuche interview partners in Wallmapu and in Europe, these bilateral relations appear as possibilities for exchanging experiences about different colonial relations of power and decolonisation efforts. These relations exist, amongst others, with Amazonian Indigenous peoples in Ecuador, sectors of the Movimento Sem Terra ${ }^{30}$ in Brazil, the EZLN in Mexico, and delegations of Aboriginal Australians. In Europe, the IDNMP has also forged relations of solidarity between the struggle of the Mapuche and the Indigenous population of the Sami in Norway and Sweden (OPAL Prensa 2016).

Besides these pan-Indigenous relations, Mapuche representatives have had direct encounters with Mapuche and European politicians. In 2014, two representatives of Mapuche communities in resistance visited German politicians and informed them about the human rights violations and their struggle in Chile. In 2015, Swedish members of the European parliament visited the Rankilko community, interviewing political prisoners and receiving information about their criminalisation. These experiences are interesting because in contrast to this transnational sphere, in the domestic context there is little dialogue between politicians and Mapuche representatives. Amina, a German solidarity activist who supported the tour of the two representatives in 2014, finds it ironic that these dialogues are possible, for example, with German politicians and not with Chileans (Amina, interview with the author, November 27, 2015). I suggest explaining this by the different treatment of the Mapuche representatives by their interlocutors. Whilst in Chile the two community representatives are considered to be Chilean nationals and members of an ethnic minority, the foreign politicians recognise them in their function as representatives of an autonomous nation. At the same time, having a conversation, or koyang, with foreign representative is a fundamental aspect of exercising the right to autonomy in the tradition of the parlamentos. 
Their autonomy is thus affirmed by the fact of having met with foreign politicians, which further serves to put pressure on the Chilean state regarding their equal status. Because, following the statement of Jaime Huenchullán, if foreign politicians are open to a dialogue with the Mapuche, why isn't the Chilean state?

Other experiences of international relations are part of the efforts of the autonomist party Wallmapuwen and the AMCAM. For example, Wallmapuwen has received visits from (and its members have visited) Catalonia and the Basque country, exchanging ideas and adjusting strategies with other autonomist political parties and organisations (Isabel Cañet, interview with the author, February 24, 2016). Isabel Cañet describes these experiences explicitly as the formation of international relations. The AMCAM has been taking an approach of establishing transnational relations, for example, by organising encounters between their member municipalities and the embassies of other nations with more advanced intercultural and plurinational jurisdiction, like New Zealand, Bolivia, or Ecuador (Mauricio Vergaras, interview with the author, February 25, 2016a). Another idea is the development of town twinnings between municipalities with Mapuche mayors in Chile and Argentina as a way of forging exchange and dialogue between Mapuche communities on both sides of the Andes and thus reconnecting the historic connections between Gulumapu and Puelmapu. These examples show how Mapuche organisations, communities, and representatives form and forge a multilayered, decentralised web of international relations beyond the political institutions of Chile by reaffirming their cultural politics of autonomy.

At the same time, this network of international relations is formed by engaging with transnational political institutions. Some investigations have already shown how international legal instruments are put to use by the Mapuche and evaluated the success of these efforts (Habersang and Ydígoras 2015; Pantel 2015). Instead of discussing the limitations and opportunities of this legal framework, a more ethnographic approach is able to reveal how these efforts are also an expression and result of the cultural politics of autonomy by the Mapuche.

In May 2015, activists of the Mapuche diaspora from the Netherlands, Belgium, Switzerland, and Germany, with the support of the UNPO and in exchange with the CTT in Wallmapu, organised a demonstration and conference in The Hague. The context was the ongoing negotiation between the Chilean and Bolivian states at the International Court of Justice regarding Bolivia's claim to have access to the Pacific. Since the Chilean state's position was 
that it "respects and obeys the integrity of the treaties agreed upon by both parties," Mapuche organisations "demand[ed] with the same degree of emphasis the compliance of the treaties or parliaments agreed upon between the Chilean State and the Mapuche People" (Mapuche Coordination Europe 2015). On the first day, a media-effective demonstration was organised in front of the Peace Palace in The Hague; the second day saw a conference with the CME, the UNPO, supporters, and invited journalists from TeleSur. The spokesman of the CTT, Aucán Huilcamán, also took part in the conference on the second day via Skype. In Wallmapu, a parallel event took place. In his presentation, Huilcamán lays down the historical grounds on which the contemporary demands are made. He specifically refers to the treaties between the Mapuche and the Spanish Crown and, later, the Chilean state, as historical precursors of the recognition of the right to self-determination by the Mapuche. A central aspect of his argument is that these treaties still have judicial value today. ${ }^{31}$ By referring to the UN Declaration on the Rights of Indigenous People, Huilcamán concludes that the Mapuche are thus affirming "a right that has been already recognised within international jurisdiction," which is why the present struggle of the Mapuche for autonomy "is not a demand, this is not a proposal - it is an already constituted right" (The Hague, group discussion, May 5, 2015).

This ethnographic account shows how Mapuche representatives strategically use the international legal framework to affirm their autonomy and independence from the Chilean nation-state. Most importantly, interventions like these are organised and exercised by Mapuche representatives (from the CTT or the diaspora) themselves and are merely supported by nonIndigenous activists and organisations. In that way, they use the international legal framework (like the UN Declaration on the Rights of Indigenous People) within supranational institutions (like the International Court of Justice) autonomously in order to achieve autonomy. In other words, autonomy is

For the purpose of this argument, Huilcamán cited the study by the former Special Rapporteur of the UN, Miguel Alfonso Martínez, on the treaties between Indigenous peoples and (post)colonial states. Huilcamán cites three conclusions of this study, which determine for the case of the Mapuche and Chile that the treaties in question are still valid, because no party renounced the agreement, no court annulated the treaty afterwards, and no party put an expiration date on the treaty (The Hague, group discussion, May 5, 2015). 
both the means and the goal of the transnationalisation of the struggle of the Mapuche.

The ethnographic experiences outlined at the beginning of this chapter point to another important aspect within the transnationalisation of the struggle of the Mapuche. In that particular situation, Mapuche representatives and the diaspora created an autonomous and protected space within encounters of solidarity. Non-Mapuche actors (like myself) and organisations were denied access to that space, in which decisions were made.

The cultural politics of autonomy hereby produce a "hidden transcript," where solidarity "takes place 'offstage', beyond direct observation by powerholders [and] consists of those offstage speeches, gestures, and practices that confirm, contradict, or inflect what appears in the public transcript" (Scott $1990,4-5)$. This hidden transcript is the result of the cultural politics of autonomy. The Mapuche diaspora and representatives from Wallmapu hereby establish clear boundaries to others, produce an inside and outside sphere of solidarity, make their network partially unintelligible, keep information safe, and reaffirm their own agency and autonomy. The mechanisms of that hidden transcript are the results of the historical experiences of colonial domination and the continuation of their struggle for autonomy and decolonisation and against paternalism. But these mechanisms do not only set up boundaries, but rather-as the concept of autonomy shows-have both centrifugal and centripetal dynamics, working as a hinge between the inside and the outside. During my militant ethnography, I experienced the role of the Mapuche diaspora as those of gatekeepers, ${ }^{32}$ who grant or deny access to that solidarity network.

The de- and polycentrality of the solidarity network already produces an unintelligibility for outsiders, and especially non-Indigenous actors and organisations. Several statements by non-Mapuche supporters reflect their lack of knowledge about the organisation amongst different diasporic Mapuche groups. For example, a staff member of the UNPO during the event in The

32 In transnational social movements, usually those organisations are described as gatekeepers "whose decisions to back a movement activate other organisations and individuals across the world. In part, this stems from gatekeepers' reputation for credibility and clout [...]. Typically, they enjoy access to other NCOs, journalists, and government officials. Even if gatekeepers do not communicate concerns directly to other network members, their choices have powerful demonstration effects, signalling that certain movements are important and certifying for support" (Bob 2005, 18). 
Hague in 2015 was not able to answer "what is the cooperation between the Mapuche groups" (The Hague, group discussion, May 5, 2015) or between them and the UNPO. Eva, who sought support for her microfinance project amongst the Mapuche diaspora, also wanted to know more about the networked structure of solidarity with the Mapuche in Europe. Although she had found some information about the network, according to her it is "totally fragmented and isolated and I am sometimes not able to find a connection and, well, I think it is totally difficult to account for a real structure and network" (Eva, interview with the author, December 1, 2015a). Sabrina (interview with the author, February 4, 2016), a non-Indigenous German woman living in Berlin, who had approached the Mapuche diaspora for information, also notes that it has been difficult for her to make sense of the networked structure of solidarity within Europe.

Peter got a similar impression of the sociopolitical organisation of Mapuche communities in Argentina during his visit to the communities in which he was shooting a short documentary about their struggle. For example, he notes that he found it difficult to "look through" or "look into" (Peter, interview with the author, December 1, 2015) the social structure of the community whilst staying there for a couple of days. This resembles not only the desire of the Western gaze to make the Indigenous intelligible, but also how this desire is countered by a hidden transcript within the sociopolitical organisation of the Mapuche. Fernando Díaz, a non-Indigenous Chilean supporter of the Mapuche in Wallmapu, explains that (Chilean) state interventions within $\mathrm{Ma}$ puche society attempt to "civilise these [the Mapuche] people" and "establish order," because "the Chilean cannot stand the natural internal tensions of the [Mapuche] communities" (Fernando Díaz, interview with the author, March 26,2016 ). These interventions mostly fail because of the state's "incomprehension that it [the Mapuche] is a different nation and it has a different dynamic." (Ibid.) The statements from Peter and Eva thus demonstrate a similar anxiety.

Thus, it seems that attempts of solidarity projects by non-Mapuche actors or organisations struggle to understand these internal tensions (their de-and polycentrality) of Mapuche communities in Wallmapu, as well as of the diasporic groups in Europe. This is why the de- and polycentrality of the sociopolitical organisation works as a hidden transcript, which is transposed to the European context of international solidarity. This creates a situation, as Alex Mora explains, in which "one cannot speak of a total transparency of knowing who-is-who a hundred percent" (interview with the author, November 28 , 2015) within the solidarity network. 
The hidden transcript thus transforms encounters of international solidarity into autonomous spaces where non-Mapuche people can participate as guests. But the main purpose is for Mapuche delegates to come together and be able to have a conversation amongst themselves, as Mauricio Vergaras (interview with the author, February 25, 2016b) explains. The hidden transcript serves to protect these spaces in their political as well as their cultural dimension. As Cecilia Necul from the autonomous Mapuche touristic project in Lago Budi highlights, some cultural elements need to stay protected from nonMapuche outsiders "because this [a particular ceremony] is something unique of us [and] we cannot show everything and let them know everything" (Cecilia Necul, interview with the author, March 10, 2016). In our conversation, she establishes clear boundaries between what can be shared with non-Mapuche and what has to remain amongst them. Certain cultural performances, as she explains, can be presented to outsiders, but their whole meaning and depth must stay within the community.

However, the unintelligibility of the solidarity structure and efforts in $\mathrm{Eu}$ rope was also criticised by some Mapuche actors. For example, Alex Mora is aware that there is need for a "greater control" (interview with the author, November 28,2015 ) within the solidarity network of people and groups who only aim to economically benefit from activism. From the perspective of Wallmapu, Isabel Cañet critically addresses the fact that organisations and communities in Wallmapu sometimes do not know what is being done within the solidarity network. For example, there is a lack of knowledge about "actions that are being done in the name of the Mapuche people" and "the political direction of these actions is not always visualised well" (Isabel Cañet, interview with the author, February 24,2016$).{ }^{33}$

Within the decentral and rhizomatic network, relations between solidarity organisations and groups in Europe are in a constant process of making and unmaking. During my ethnography, I developed a mapping system, creating an overview of solidarity events, actors, and topics across Europe. As I added more and more content, this map took the shape of a networked fabric that is being woven through the agency of the Mapuche delegations and diaspora. I borrow this metaphor from the solidarity campaign tour from 2014 by María Teresa Curaqueo Loncón, a Mapuche weaver-a rather prestigious and important activity for the Mapuche.

33 These critiques will be further elaborated on in the discussions of chapter six. 
I wanted to follow up on her experiences in Europe and interviewed her in 2016 (María Teresa Loncón, interview with the author, March 3, 2016). She presented weaving as an activity within Mapuche society that comprises sociopolitical, cultural, cosmological, and symbolic aspects. According to her, weaving has always been present in Mapuche society and has mostly been done by Mapuche women, (re)producing communal bonds and symbolic elements of the Mapuche culture. For her, weaving is an ancestral mandate for the Mapuche women, where cultural, cosmological, and political symbols are transmitted through the fabrics whilst the knowledge about the weaving itself is part of an oral tradition. Of her experience in Europe, she notes that she made connections and discovered commonalities with other people through the activity of weaving. In her words, "the fabrics surrounded us" (Ibid.). Indeed, the shared practice of weaving has been noted to contribute to strengthening a decolonial and feminist identity, as well as the communal ties surrounding it (Rivera Cuscanqui 2018, 94-95; Sempertegui 2020, 126-128).

Consequently, I adopt the metaphor of weaving to describe the processes through which the transnationalisation of the struggle of the Mapuche and its international solidarity relations forge communal ties amongst the Mapuche (in diaspora and Wallmapu), as well as relations with non-Mapuche actors and organisations. As a historically feminised task, the weaving metaphor further accentuates the role of diasporic Mapuche women building communal ties amongst the diaspora and with Mapuche delegations from Wallmapu within transnational advocacy and solidarity. In summation, Mapuche actors themselves weave the decentral, rhizomatic solidarity network in an open-ended and contingent process, with multiple endings and extensions.

This weaving process is both targeted towards the Mapuche community and towards the non-Mapuche world. It is thus both centripetal and centrifugal. On the one hand, it composes transnational (between Chile and $\mathrm{Eu}$ rope) and translocal (between particular groups in Europe and Wallmapu) sociocultural relations amongst the Mapuche. On the other, these Mapuche groups and organisations weave relations of solidarity with non-Mapuche actors and organisations. The centrifugal force has its gravitational centre both in Wallmapu, from where organisations and communities seek alliances beyond Chile, as well as in Europe, from where the Mapuche diaspora is constantly mobilising support with the non-Mapuche world. Building alliances with non-Mapuche actors and organisations is part of the "external self-disposition" of the Mapuche society, which demands "the creation of networks with other countries and the international political community" (Marimán 
et al. 2006, 255-56). But these alliances always have to meet the conditions of "recognising our autonomy and respecting our internal resolutions, recognising our sovereignty in our territorial limits" (Marimán et al. 2006, 255-56; my translation). Nevertheless, this external self-disposition (or centrifugal dynamic) is only secondary to the "internal integration" of the geographically dispersed Mapuche society (Ibid., 247).

Mapuche organisations and communities from Wallmapu have managed to weave alliances with a series of actors and organisations on an international and transnational level. Between 2014 and 2017, several representatives of Mapuche communities and organisations, as well as individuals, have travelled to Europe, weaving the international solidarity network. They have formed relations and alliances with non-Mapuche actors, which include a) other Indigenous or government representatives, b) local solidarity groups, including those of the Mapuche and Chilean diaspora, c) a series of nongovernmental organisations that contribute to transnational Mapuche advocacy, d) efforts within international and transnational governmental institutions like the UN or the European Parliament, and finally e) contacts with individual non-Indigenous supporters.

Several Mapuche interlocutors in Wallmapu and Europe point out that the struggle of the Mapuche goes beyond the political sphere and includes cultural, social, cosmological, epistemological, and other aspects. For José Luis Calfucura (interview with the author, February 16, 2016a), the struggle of the Mapuche takes place within different trincheras (trenches). To him, cooking is an opportunity to revitalise the culinary traditions of his people and to make them available to non-Mapuche. His trinchera, the cooking, opens up a space from which transcultural relations with the non-Mapuche world in Chile and beyond can be established.

The idea of different trincheras of international solidarity echoes the multidimensionality of the cultural politics of autonomy, including cultural, social, cosmological, and other elements. Denouncing human rights violations, organising protests in support of the political prisoners, or Mapuche delegations intervening in supranational organisations must be read as only one aspect of international solidarity. As Isabel Cañet claims, the international solidarity efforts must "make visible many more issues, above all everything that aims to make a political project behind it visible" (interview with the author, February 24, 2016). Accordingly, this last section addresses how and why transnational and translocal relations of solidarity take place across multidimensional spheres of social, political, and cultural life. 
Some aspects of the solidarity network in Europe (for example, the celebration of the wetripantu) were already presented as having an essentially sociocultural, cosmological, and religious dimension. Also, understanding the political expressions of solidarity is only possible by starting from the sociocultural connections the Mapuche diaspora has been weaving since the late 1970s. Today, efforts to support Mapuche communities and organisations are also taking place in the areas of (endogenous and exogenous) development projects ${ }^{34}$ as well as (autonomous) tourism projects. In these trincheras, tourism, for example, is a means to become economically self-sufficient and politically autonomous (Cecilia Necul, interview with the author, March 10, 2016).

The most important trinchera is the one to revitalise the Mapuche culture, particularly Mapuzugun. For example, the educational collective Kimeltuwe promotes Mapuzugun by creating digital (on social media) and analogue educational material. Victor Carilaf, co-founder and teacher of Kimeltuwe, explains that their aim is to focus on something different than the political struggle, because there are already enough media sites for that. Instead, they intend to "revitalise Mapuzugun" (interview with the author, February 23, 2016). Similar to the comments of José Luis Calfucura, they want to display and represent Mapuche culture in a more positive and easily accessible way beyond (but without ignoring) the violence of the conflict in Wallmapu.

Mapuche artists travelling to Europe also contribute to weaving the solidarity network. In recent years, the Mapuche poet Rayen Kvyeh, the weaver Maria Teresa Loncón, and the rapper Waikil have made one or several trips to Europe to represent, transform, or transculturalise Mapuche culture through their artistic work. These cultural expressions are not detached from the repression or persecution of the Mapuche in Wallmapu but contribute with a different perspective and positionality to offer a better understanding of their situation. Rayen Kvyeh explains that her poetry "speaks of the incarcerated rivers, [...] as well of the rivers, lakes, and seas that are being contaminated and taken hostage by the power dams" (interview with the author, March 1, 2016). She is convinced that she raises more consciousness in Europe with her poetry than with political discourse, "because anyone can engage in a political discourse" (Ibid.). Rather, and in order to be able to speak "of the voices of the incarcerated rivers, speaking [...] about how the life of a tree has been cut for 
the sake of the international timber market, speaking of the draught that destroys our communities today" (Ibid.), she does not need a political discourse other than her poetry. Rayen Kvyeh shows not only how poetry can become a more effective tool for raising consciousness for international solidarity; what is more, her poetry gives a voice to the nonhuman and thus challenges the anthropocentrism of Western thought.

Interventions of Mapuche artists in transnational spheres of solidarity go well beyond the political dimension. Like the recreation of cultural practices in urban spaces in Chile (Becerra et. al. 2017), they contribute to revitalising Mapuche culture abroad, but also to building transcultural bridges towards the non-Mapuche world. Being active in different trincheras, they are not only able to reach a wider non-Mapuche audience, but open the conversation for other sociocultural, cosmological, or epistemological perspectives as transcultural translators.

This chapter suggested understanding international solidarity with and of the Mapuche as a transnational expression of their cultural politics of autonomy. This is because Mapuche representatives from Wallmapu and from the European diaspora have transnationalised their struggle since the 1970s and have woven a decentral, contingent, and rhizomatic network by establishing relations of support and solidarity with other actors whilst remaining the protagonists and maintaining their autonomy.

Based on the historical experiences of autonomy of the Mapuche society, the shared horizon of autonomy amongst Mapuche organisations and communities today, and discussions about autonomy within critical Mapuche studies, I suggested a conceptual approach to autonomy as Mapuche cultural politics. This notion of autonomy is conceptually heterogeneous, based on the shared colonial experience of the Mapuche population, linked to the territory, formed in a collective process, and mediates difference towards the non-Mapuche world. It is furthermore, as expressed in the notion of kisugvnewvn, a form of individual micropolitical self-government within a wider sociopolitical network.

The second part traced the transnationalisation of Wallmapu, which has been understood as a site of resistance and hope since the 1970s by Mapuche representatives and a growing Mapuche diaspora. The first generation of the Mapuche diaspora in Europe hereby constitutes the major precedent of contemporary solidarity efforts. The Mapuche diaspora today organises solidarity alongside interpersonal and kinship networks, transculturalises spaces and 
sites of political activism, and is characterised by the strong agency of Mapuche women.

These actors (Mapuche representatives from Wallmapu and the diaspora in Europe) weave international solidarity as a decentral, contingent, and rhizomatic fabric whilst maintaining their autonomy. In that way, the cultural politics of autonomy of the Mapuche are being transnationalised, inform, and ultimately shape the solidarity and advocacy network. The chapter went on to describe relations of solidarity with non-Mapuche actors and organisations as international and bilateral relations, whilst the internal dynamics of this network are rarely divulged to non-Mapuche outsiders and are thus kept hidden. As a last feature of this network, I suggested considering solidarity efforts of/with the Mapuche beyond the political sphere and to include the cultural and social dynamics at play.

In this woven network of international solidarity, non-Mapuche actors and organisations, together with Mapuche representatives from Wallmapu and diasporic Mapuche living in Europe, participate in transnational Mapuche advocacy (TMA) and have developed a series of advocacy strategies, which will be the topic of the following chapter. 
